\title{
生息域の季節変動に着目した \\ 魚類生息域適性基準に関する研究 \\ SUITABILITY CRITERIA FOR FISHES \\ FOCUSING ON SEASONAL CHANGE OF FISH HABITAT
}

\author{
知花武佳 ${ }^{1} \cdot$ 玉井信行 $^{2}$
}

Takeyoshi CHIBANA and Nobuyuki TAMAI

\begin{abstract}
${ }^{1}$ 学生員 東京大学大学院工学系研究科 社会基盤工学専攻 博士課程 （T113-8656 東京都文京区本郷 7-3-1）
${ }^{2}$ フェロー会員 東京大学大学院工学系研究科 社会基盤工学専攻 教授 （テ113-8656 東京都文京区本郷 7-3-1）
\end{abstract}

PHABSIM is one of the most famous methods to estimate condition of fish habitat. Recently many researches are performed to improve PHABSIM. In this study we derived the criteria for habitat of Japanese dace (Tribolodon hakonensis). At first, we paid attention to the seasonal change of Japanese dace's habitat. Japanese dace utilized a different area in each season, but the local condition of depth and velocity was approximately constant all the year round. So we clarified that the neighboring condition affects the condition of fish habitat. Next, we evaluated the effect of morphological changes on the fish habitat, and we clarified that flattening of sand bars and local incisions of riverbed cause the degradation of fish habitat. So we improved original PHABSIM to estimate the morphological impacts, and suggested the new suitability criteria of Japanese dace based on rapid-pool conditions.

Key Words : PHABSIM, suitability criteria, rapid-pool condition

\section{1. 研究の背景と目的}

近年，河川に生息する様々な生物の生息環境に配 慮した河川管理が行われるようになってきたが，正 常流量 ${ }^{1)}$ としてどの程度の流量を確保すべきかとい う問題に対しては，明確な答えが出せない状況にあ る。そのような中で注目される手法の一つが PHABSIM(Physical HABitat SIMulation model)であ る ${ }^{11}$. 本手法は, 魚類の生息域を水深, 流速, 底質 といった各物理環境指標に対する魚類の適性基準を 設けて定量的に評価する所にその特徵がある.また， その構造は比較的簡潔ではあるが，我が国の河川に 適用された既往の研究においても，その効果が証明 されている2゙.

しかし，その簡潔な構造故に，いくつかの欠点が 指摘されており，これまでもいくつかの改良が試み られてきた．例えば，個々の物理環境指標を対等に 取り扱っているという問題を指摘し適性曲線に重み 付けを行ったもの ${ }^{3)}$ や, 採餌や避難といった各行動 特性に対応した場の連結性を取り込んだもの ${ }^{4)}$ など があげられる.このように PHABSIM における問題点
が，1）個々の環境因子を単独かつ対等に取り扱つ ている点，2）評価值はある一点だけの情報で求ま り，周囲の環境が全く考慮されていない点，にある ことは各研究者間で共通している.そこで筆者らは， 既往の研究において, 瀬一淵構造内での相対的位置 と瀬，淵自体の評価值を組み合わせた新手法を提案 している ${ }^{j)}$.この中で我々は, 魚類が瀬一淵構造内 で特定の部位を選好するという特徵に着目したが， 本研究においてはウグイが選好している領域が経年 的にどのように変化したのか，またそれを支配して いる因子が何であるかを追究することにより，従来 の適性基準に改良を加えることを目的とする。

\section{2. 対象地区}

本研究の対象としたのは, 多摩川河口から約 52 $\mathrm{km}$ 上流付近に位置する一組の瀬と淵を含む約 $200 \mathrm{~m}$ の区間である. 本地区は, 多摩川扇状地上に位置し 河床勾配約 1/218，対象区間内の水域における平均 粒径は $56 \mathrm{~mm}$ であった. また，本対象区間の直上流に は羽村堰があり，ここでの取水のために対象区間の 
流量は洪水時を除き年間 $2 \mathrm{~m}^{3} / \mathrm{s}$ で一定である.さら に, 砂利採取やダムや堰の影響を受け, 河床低下も 顕著になってきているなどさまざまな問題が指摘さ れている ${ }^{6)}$. また, 本研究においては, 1997 年 11 月〜1999 年 11 月の間に行われた 4 回の調査結果を 取り扱うこととする.この間 1998 年 8 月までは大き な出水はなかったが，1998 年 9 月，及び 1999 年 8 月に，本区間よりも下流に位置する多摩川石原地点 で, ピーク流量 $2180 \mathrm{~m}^{3} / \mathrm{s}$, 及び $2620 \mathrm{~m}^{3} / \mathrm{s}$ の出水が あったために，その地形は大きく変化した ${ }^{6)}$.

\section{3. 水深, 流速に対する選好性の季節変化}

従来の適性曲線では, 横軸に水深又は流速, 縦軸 に個体数をとって比較されることが多いが, 水深や 流速が独立の変数ではない点と, 個体数だけではそ の選好性が不明瞭である点を踏まえて, 横軸に水深, 縦軸に流速をとった平面上に, Ivlev の餌選択指数 を用いた適性值をプロットしたもの7)を用いた。図 -1は, 各調査時期におけるウグイの水深, 流速に対 する適性值を季節毎に示したものである. 先に述べ たように, 流量は一定であるために, 出水後の 1999 年 11 月以外, 水深流速分布に大きな違いは見られな い.図を見てわかるように, ウグイの選好する水深， 流速の範囲は季節を問わず $0.5 \mathrm{~m}$ 及び $0.5 \mathrm{~m} / \mathrm{s}$ を中心 とした領域で，11月にやや深い領域での適性值が高 くなる以外変化は見られない。.また，水深に関して は水深 $30 \mathrm{~cm}$ 以下の領域がほとんど利用されておら ず，これが閾值となっていることがわかるが，流速 に関しての閾值はここからは読みとれない。

\section{4. 瀬一淵構造内での選好箇所の季節変化}

前章において, ウグイが選好する水深, 流速の範 囲は年間を通じて変化していないことを示したが， 例え水深, 流速が等しくとも, 瀬一淵構造内での相 対的位置が異なればその環境は大きく変化する ${ }^{5)}$. そこで, 本章では生息域の瀬一淵構造内での相対的 な位置に着目する。

ここで，瀬一淵構造内で相対的にどの位置にいた のかを明瞭に示すために, 我々が提案した瀬一淵構 造無次元表記法について説明する.

まず，河道の淎筋に沿った縦断方向の水深分布に 着目する.ここで, 最も浅い早瀬の水深 $\mathrm{h}_{0}$, および 最も深い淵の水深 $\mathrm{h}_{1}$ を基準とする.すると，ある任 意の水深 $\mathrm{h}_{\mathrm{x}}$ に対応した位相 $\theta_{\mathrm{x}}$ は次式によって求め られる。

$h_{x}=\frac{\left(h_{0}-h_{1}\right)}{2} \cos \theta_{x}+\frac{\left(h_{0}+h_{1}\right)}{2}$

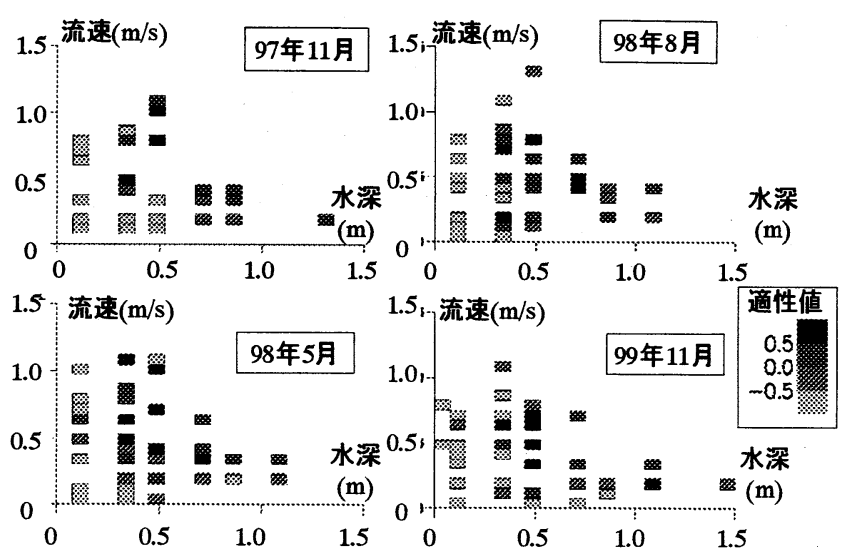

図-1＼cjkstart各季節におけるウグイの水深, 流速に対する適性值

この任意の地点が，早瀬〜淵中央部の間に位置す る点であれば, $0 \sim \pi$ の間の值を与え, 淵中央部〜次 の早瀬の間に位置するときには $\pi \sim 2 \pi$ の間の值を 与える. そうすれば，澪筋の水深に対応した位相が 求められ，同じ水深でも淵中央部より上流か下流か によって違う位置情報を与えることができる．

次に同様の概念を横断方向にも適用する．今度は 断面内で, 最も深い淎筋上の水深 $\mathrm{h}_{\mathrm{max}}$ を基準とする と，ある任意の地点における水深 $\mathrm{h}_{\mathrm{y}}$ に対応した位相 $\theta_{\mathrm{y}}$ が次式によって求められる.

$h_{y}=h_{\max } \theta_{y}$

ここでは, 淎筋より右岸側に 0 $\pi / 2$ の間の值を， 左岸側に $\pi / 2 \sim \pi$ の間の值を与えることで, 同じ水 深であっても区別が可能である.

ここで澪筋に沿った水深も一様に増加，減少して いくわけではないので, 順序が前後する点や，実際 の面積を反映できない点などの欠点がある.しかし， 逆に様々な水深の環境がまんべんなく存在するのか， ある水深に偏った分布をしているのかなど，水深の 多様性を判断できることや，規模の全く異なる河川 間での分布傾向の比較を行う事も可能となる ${ }^{8)}$. ま た，魚類の生息域は水深，流速に関わらず，瀬一淵 構造内での特定の部位に限られていることが多いの で，その条件を定量的に与えることもできる ${ }^{5)}$.

この手法を用いて，横軸に縦断方向の位相，縦軸 に横断方向の位相をとった図上にウグイの生息密度 をプロットしたものが図-2 である。ここで， $\mathrm{x}=0$ 及 び 6.28 が早瀬の断面, $\mathrm{x}=3.14$ が淵の断面に相当す る. また $\mathrm{y}=1.57$ が淎筋に相当し, 流れは左から右 である.また, 今回の対象区間では, 上流から早瀬, 早瀬と平瀬の中間, 砂州を横切る早瀬, 淵の順に並 んでいるが，基準としては，上流側の早瀬における 水深と淵の水深をとった.

これらの図を見比べると，季節によってその選好 する場所が変化している様子が見て取れる. 出水に 

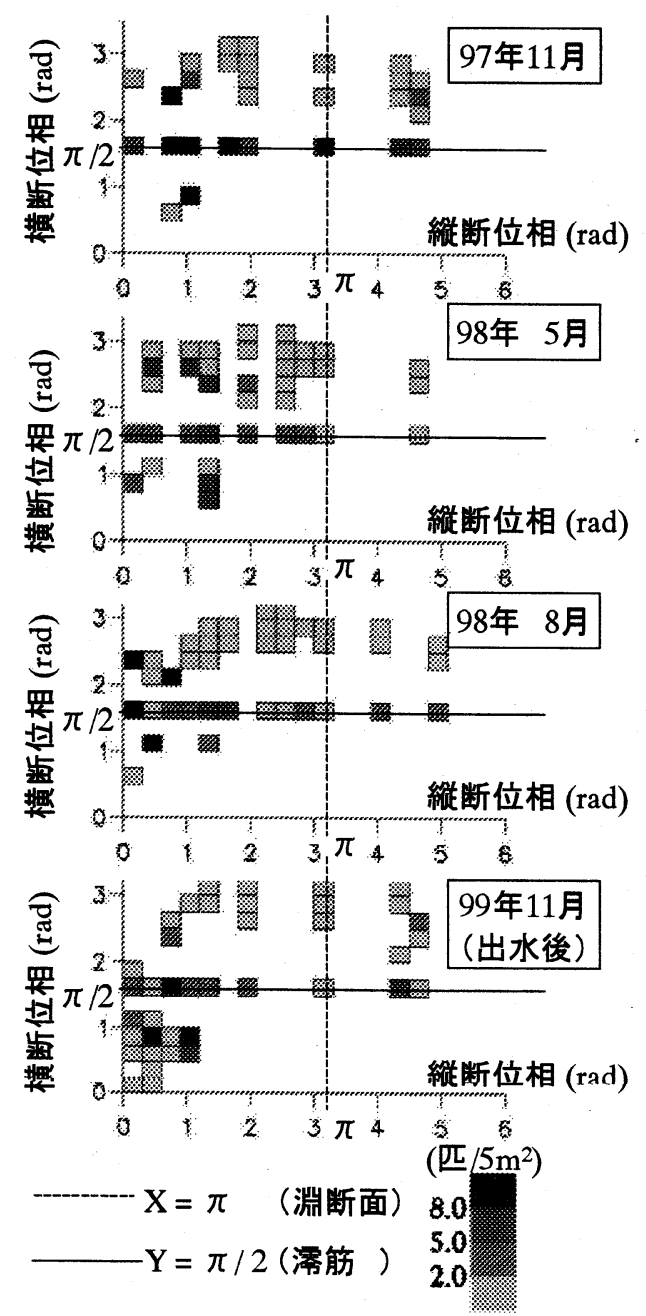

図-2 無次元表示法を用いた瀬淵構造内におけるウ グイの分布の季節変動

より地形が変化した 1999 年 11 月を除き, 水深, 流 速分布はほとんど同じであるために，このような生 息域の変化は，水深流速分布では説明が付かない. そこで，季節による分布の違いをもう少し細かく見 るために，図-2 と共に，生息密度が最大值を示した 点における, 水深, 流速の值および淵頭，瀬尻の別 を元に考察していくこととする. 二回の出水後であ る 1999 年 11 月に関しては次章でその考察を行う.

まず，1997 年 11 月に，もっともウグイの密度が 高かった地点は, 水深 $0.44 \mathrm{~m}$, 流速 $0.51 \mathrm{~m} / \mathrm{s}$ で瀬に 位置しており，1的あたり 12 匹が確認されている. また，図-2より，瀬のやや深くなったところから淵 の前半分にかけて選好度の高い領域が広がっている 様子が分かる. 98 年 5 月になると, 全確認個体数が 減少するが, 淵頭において水深 $0.62 \mathrm{~m}$, 流速 $0.42 \mathrm{~m} / \mathrm{s}$ の地点において， $5 \mathrm{~m}^{2}$ あたり 16 匹というのが最高密 度である. 図をみると，この時淵中心部を利用する 個体はほとんどおらず，その大半が瀬から淵頭にか けての領域に生息していることがわかる.8 月にな ると，瀬に対する選好性はより強まり，瀬の流心部
付近に個体が集まっている様子が見て取れる.しか し, 最も密度が高かったのは, 瀬脇であり, 水深 $0.44 \mathrm{~m}$, 流速 $0.2 \mathrm{~m} / \mathrm{s}$ の地点で $1 \mathrm{~m}^{2}$ あたり 9 匹が確認 された.

このように，もっとも密度の高い一点について見 ても, その水深, 流速はある程度似た值であるもの の，その瀬一淵構造内での位置は変化している.す なわち, 年間を通じて瀬から淵頭にかけての領域で の選好性が高いが，水温の高い夏には淵をあまり利 用せず，その大半が瀬を中心に活動していることが わかる.また，秋においては瀬で最も多くの個体が 確認されたものの，淵中心部近くまで広くその生息 域が広がっているが, これは, 全個体数が多いこと と, 水温が下がってきたために深場への選好性が増 したためと思われる. 春には, 秋に比して全個体数 が少ないこともあり,淵中央部にはあまり見られず， 瀬中心にウグイがみられるものの, 最大密度は淵頭 で観測されており，淵への依存性も伺われる.この ように，季節によって活動の中心が瀬と淵頭の間で 微妙にシフトしている様子が見て取れる.

\section{5. 出水による河床形状変化に伴う影響}

次に, 1997 年 11 月のデータと 1999 年 11 月のデ 一夕を比較することにより, 出水による河床形状の 変化が生息域にどの様な影響を与えたかを考察する. 上述した二回の出水により, 環境がどのように変化 したかをまとめたものが図-3である

まず，図-3a)に示したように，左岸側の砂州の比 高が減少し, 半分以上が水面下となった. 図-3a)中 $A B$ 線に沿った断面形上の変化を図-3b)に示してあ る. 低水路内では, 砂州の比高が減少すると共に湊 筋部の水深が浅くなり全体的に平坦化した様子が見 て取れる.また,砂州の前縁線は上下流に長く延び, これを横切る早瀬はその幅を増している.このため, 四中の模式図に示したとおり，出水前に淵頭であっ た所には水が集まらず，ここでの単位幅流量は減少 する結果となった.このような平坦化と単位幅流量 の減少に伴い, 淵頭は浅く遅い流れとなり, 生息適 性度は低下した。一方, 淵中心部の水深は逆に 30 cm程度深くなったことで, 瀬と淵の水深は二極化の 傾向を示し, 図-2の 1999 年 11 月の適性基準に示さ れるとおり, 縦断方向の位相が $\pi / 2 \sim \pi$ の領域が減 少し,0〜 $\pi / 2$ の範囲の水樑に偏っている.また 1997 年 11 月には比較的利用されていた淵の深い領域は, 1999 年 11 月の水理量においても従来の適性曲線 ${ }^{1)}$ では評価值が高い領域にあるにもかかわらず，あま り利用されていない，そこで, 淵の状況を詳しく調 べるために図-3a)の CD 線に沿った断面内の流速コ 


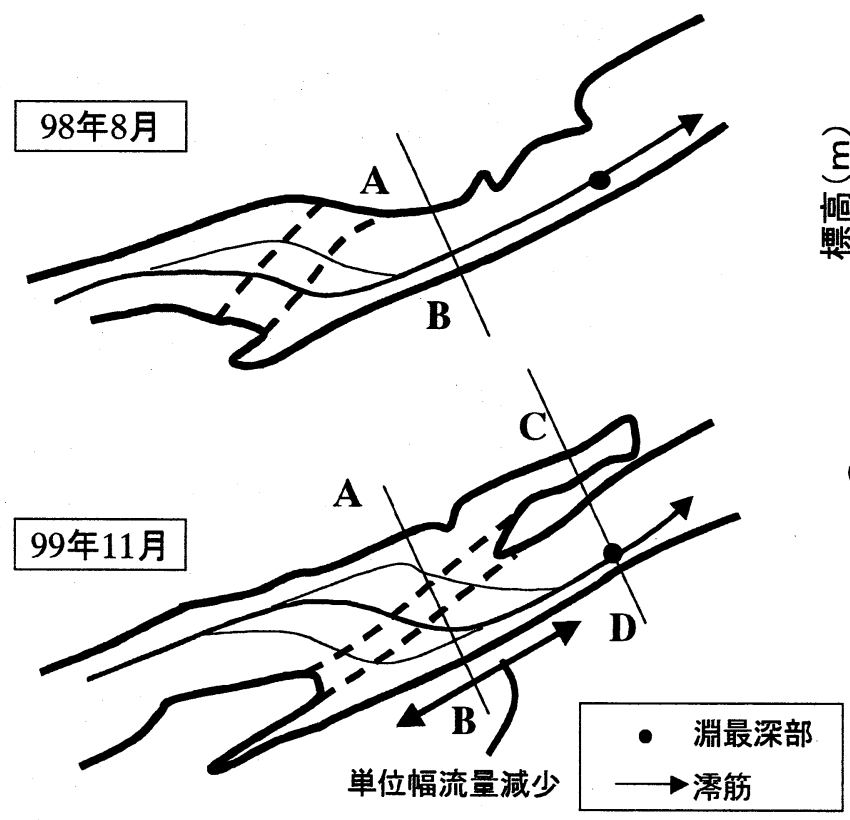

a) 出水に伴う水際線及び水面形状の変化

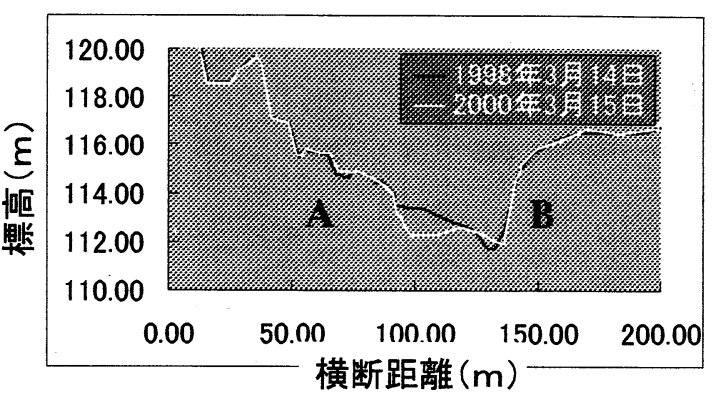

b) 低水路内, 河床高の平坦化

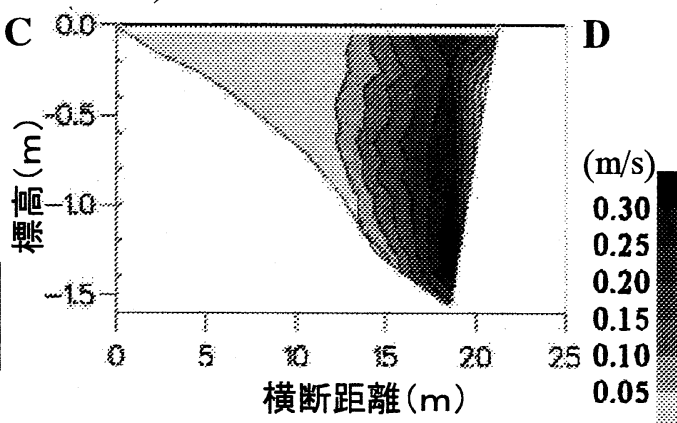

c) 淵最深部を含む断面内の流速コンター

図-3 出水に伴う地形変化と地形変化後の断面内流速分布

（横断面デー夕は国土交通省国土技術政策総合研究所の提供による）

ンター図を図-3c)に示した。これを見ると，流れは 淎筋付近のみに，水面から河床までほぼ一定の流速 が流れていることが見て取れる。これは，以前に比 べて流れが河岸に垂直に近い角度で入ってくるため に (図-3a)), 流れが河岸近くに限定され内岸が止水 域になったという地形による影響と，流量が変わら ぬまま洗掘により河積が広がり流れが停滞したこと が理由として考えられる，底面付近で流速が最大值 を取っているのも地形に伴う流れの偏りの影響によ るものと推測される。

\section{6. 評価基準の作成}

これまでの結果を基にウグイ生息域の特徵をまと める.まず，本来ウグイは年間を通じて淵中央部に かけても多いはずであるが，春と夏に利用されてい たのは瀬から淵頭だけであり，1997 年秋にはまだ利 用されていた淵最深部付近も，1999 年秋にはあまり 利用されていない点に着目する．このようにウグイ が淵頭のみを利用しているという現象は，取水に伴 い，流量が本来あるべき状態より減少している区間 （減水区間）においてしばしば報告されており，こ の理由は淵における流れが停滞したためといわれて いる 9 .ここで,この停滞の意味について考察する.

図-1 を見てもわかるとおり流速自体は $0.1 \mathrm{~m} / \mathrm{s}$ 前後 の所でも選好度が高い領域は存在する上，規模が小 さい河川における淵では，流速が永田地区よりも小 さくとも充分な密度が確認されることもあり ${ }^{8)}$ ，流
速自体がその主要因とは考えにくい.しかしながら， たとえ流速が同じ值であったとしても，水深が深く なればそれだけ水深方向の流れの変化は乏しくなり， ウグイのように流れに変化のある環境を好む魚にと って好ましくない状態であると考えられる．淵頭の みを利用しているという現象もこれを裏付けている.

もう一つの特徵は, ウグイが生息していた場所の 水深, 流速といった值は年間を通じて変化しないも のの，その中心は季節によって瀬であったり，淵頭 であったり変化している点である.

これら二つの特徵を考虑し, 次のような行動パ夕 ーンの仮説を立てた.すなわち，1) ウグイが活発 な時期は，平面的に流れが多様な瀬を中心に採飳を 行っており，その中でやや流れの緩やかな領域を中 心に, 時々その周囲で流速が $1 \mathrm{~m} / \mathrm{s}$ を越えるような場 所にアクセスする. 2 )ウグイの活性が低い時期は, 平面的には流れがあまり変化しない淵の中で，河床 近傍から表層へ向かっての緩やかな流速変化を活用 し，時々上層部へ移動し採餌する。これらをもとに 評価法の開発を行う.

すると，瀬においては，流れの速い領域と遅い領 域が混在するような状態が，淵においては，水深方 向に流速が変化していくような状態が生息域の条件 となる. 出水に伴う淵の洗掘は, 水深方向の流速変 化を乏しくさせ，ウグイにとっての淵の適性度は低 下したと考えられる.すると，1997 年 11 月に比心゙ て 1999 年 11 月には淵全体の利用度が低下したこと も説明が付く.そこで，この現象を定量的に表現す 
るために，図-1 同様水樑，流速平面上で，ウグイが 通常生息している領域 (生息適性領域)，瀬にいるウ グイが時々アクセスする流れの速い領域(高流速域), 減水区間の淵に見られるように変化に乏しく利用さ れにくい領域（停滞域）の3つを表現し，これらを 用いて瀬，淵の機能を評価する手法を提案する. 図 -4 はこれらの領域を水深一流速平面上に示したも のである. 図中には，従来の第一種適性基準 ${ }^{1)}$ にお いて, ウグイ成魚の適性值が 1.0 となる領域も破線 で示してある. 減水区間の淵においては, 発見個体 数が少ないにも関わらず PHABSIM による評価值が高 めに出るのは，この停滞域を高く評価していること によるものと考えられる. また，PHABSIM において は，0-1の中間の適性值をとる領域を与えているが， 本論文においては，簡単のため，基準值をクリアし ているか否かで評価を行う．まず，これまでのデー 夕に基づき水深の下限は $0.3 \mathrm{~m}$ 設定した. 次に上 述した $3 つ の$ 領域を分割している(1)〜 (3)の 3 本の曲 線をどのように求めたかを述べる.

まず，淵において流れが水深に応じた適切な範囲 にあるか否かを(3)の曲線で分けた。これは，次式に 従い導いた。

$$
\begin{aligned}
& \bar{u} / u_{*}=5.75 \log _{10}(H / k s)+6.0 \\
& u_{*}=\sqrt{g H I}
\end{aligned}
$$

ここで, $\bar{u}:$ 平均流速, $H$ : 水深, $k s$ : 相当粗 度， $u_{*}$ : 摩擦速度，I: Iネルギー勾配である. 対 象が淵であることを考慮して，現場の底質状況から $k s=0.3 \mathrm{~m}$ を仮定した. また，図-1 の結果より， I=1/10000 程度が妥当であると判断し，この值を代 入して(3)の曲線を得た。むろん，現実の流れは等流 ではないためこの式から算出される值は近似值であ るが, 水深方向に流速の変化があるかないかを決め る一つの基準としては利用できると考えている ${ }^{10)}$. また， Fr 数を用いて，瀬淵の状態を判別するという 試みもいくつかなされているが 11)12)，この場合 $\mathrm{Fr}=0.1$ に相当する曲線がこの(3)の曲線と極めて近 い挙動を示している.

次に(1)と(2)であるが，ここでも流速分布は対数則 に従うと仮定した。

$$
u / u_{*}=5.75 \log _{10}(h / k s)+8.5
$$

ここで, $h$ : 河床からの高さ $(0.1 \mathrm{~m}), u$ : その位 置での流速，である. また，ここでは早瀬であるこ とを考慮して， $k s=0.5 \mathrm{~m}$ を用いる. (1)と(2)の基準と して, 河床近傍の流速に着目した. 対象であるウグ イ成魚のサイズを考慮して河床から $10 \mathrm{~cm}$ 上に於け る流速を考え，生息適性領域の上限を $0.6 \mathrm{~m} / \mathrm{s}$ ，アク セスできる高流速域の上限を $0.8 \mathrm{~m} / \mathrm{s}$ と設定し,これ

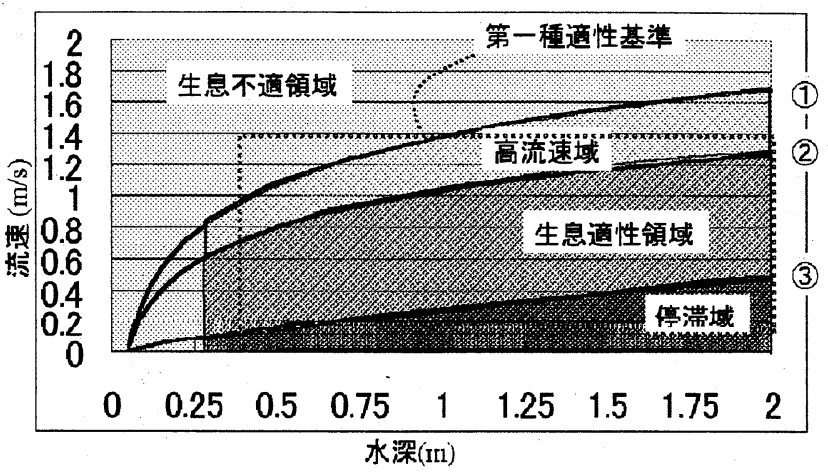

図-4＼cjkstart新たに作成した適性基準案

らと，式(3)から算出される $u_{*}$ を, 式(5)に代入する ことにより, 平均流速と水深の関係が求まり，曲線 (1)，(2)を描くことができる.

\section{7．新適性基準に基づく評価と考察}

新しく作成した適性基準を用いて，1998 年 8 月と 1999 年 11 月の水深, 流速分布をもとに, 生息適性 領域，停滞域，および高流速域に分けて図-2 同様の 表記法を用いたものが図-5である.

出水前には淵中央部（縦断位相が $\pi ）$ 付近の領域 が利用されていたものの, 出水後は利用されなくな ったという現象が図-2で見られたが，これは淵中央 部の環境が生息適性領域から停滞域へと変化したた めであるということが，図-5で表現できている。従 来の適性曲線を用いた場合は，この停滞域の評価値 も高くなることを考えれば，改良の効果が見て取れ る.

次に，これらの評価基準をもとに，ウグイの生息 域に影響を及ぼす各領域の面積比を瀬, 淵に分けて まとめたものが表-1 である.ここでの瀬淵の区分は， 河床勾配の変曲点で区分し ${ }^{13)}$, 簡単のため, 面積の 代わりに河道内をほぼ等面積で分割したセルの数を 用いた.ここで, 流量は出水前後で変化していない にも関わらず，出水後は淵より瀬の割合が増加する と共に，淵においてもともと多かった停滞域がさら に増加した様子が分かる．また，この評価によれば 瀬の適性領域は広がったものの, 高流速域はさほど 増加しておらず，流速場の多様性はあまり向上して いないと判断される.6章で述べたように瀬におけ る遅い領域と速い領域を行き来しながら摂餌してい るという仮説に基づけば，瀬の適性度も低下したこ とになる.この観点で図-2を見れば，瀬において選 好されていた環境は限られており，この仮説は妥当 であったと推測される.このように，様々な場を区 分しその量在評価することで，場の多様性を定量的 に議論することが可能となる。 

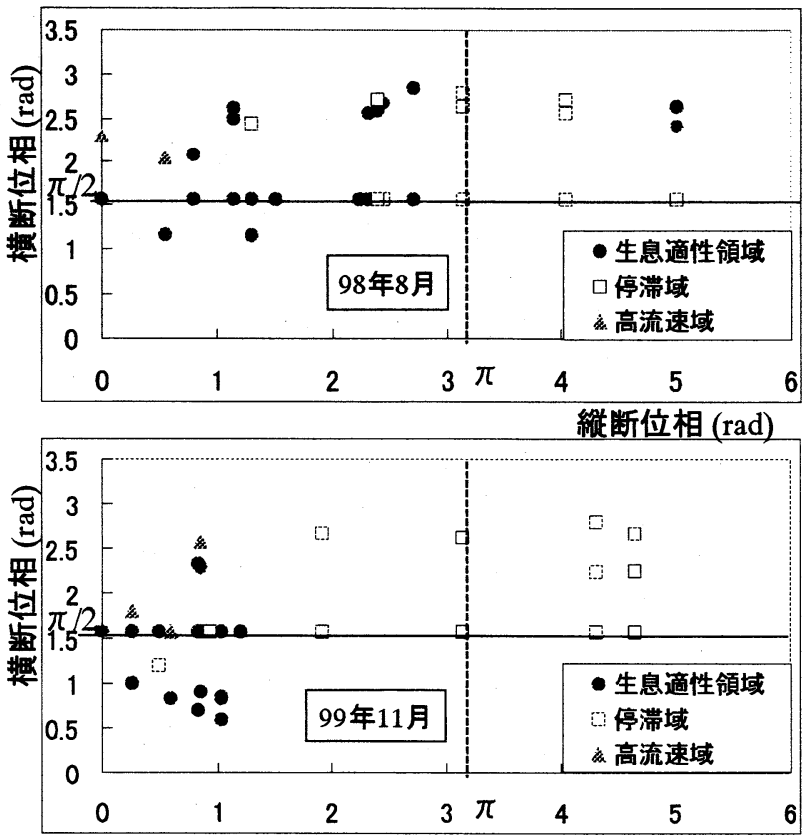

綖断位相 ( $\mathrm{rad})$

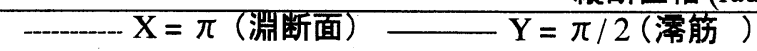

図-5 無次元平面上で表される,新基準に基づく属 性の分布

表-1 各領域の面積比率の変化

\begin{tabular}{|c|c|c|c|c|c|c|}
\hline & & $\begin{array}{l}\text { 生息適 } \\
\text { 性領域 }\end{array}$ & $\begin{array}{l}\text { 高流 } \\
\text { 速域 }\end{array}$ & 停滞域 & $\begin{array}{l}\text { 生息不 } \\
\text { 適領域 }\end{array}$ & 合計 \\
\hline 98年 & 瀨 & 9 & $\overline{2}$ & 1 & 8 & 20 \\
\hline 夏 & 流 & 1.1. & 0 & 10 & 14 & 35 \\
\hline 99年 & 瀬 & 18 & 3 & U & 17 & 37 \\
\hline 秋 & 瀟 & 11 & 0 & 14 & 8 & 23 \\
\hline
\end{tabular}

\section{8.まとめ}

本論文では, ウグイが水深, 流速の值だけでなく, 周囲の環境との関係の中で, 生息域を季節により変 えていることを明らかにし, 従来の水深流速に基づ く適性曲線に改良を加えることで，瀬－淵内でウグ イの生息域に影響を与えると考えられる場の特徵を 表現できた。

今後は底質の条件を評価すると共に，産卵，避難 など他の行動も考慮した総括的な評価法を提案する ことが課題となる。

謝辞 : 本研究は河川生態学術研究会の研究の一環 として行われたものである. 魚類デー夕を提供して くださった君塚芳輝氏, 河床横断面デー夕を提供し てくださった国土交通省国土技術政策総合研究所河
川研究部河川研究室の皆様を始め, 関係者の皆様に 深く感謝いたします。

\section{参考文献}

1）アメリカ合衆国内務省・国立生物研究所（テリーワド ウル・中村俊六訳) : IFIM 入門, 財団法人リバーフロ ント整備センター, pp.145-150，1999.

2）小出水規行, 藪木昭彦, 中村俊六 : IF IM/PHABSIMに よる河川魚類生息環境評価一豊川を例にして一，河川 技術に関する論文集 第 6 巻, pp.155-160，2000。

3）原田守啓，藤田裕一郎，深谷治由: 河川の生息環境評 価手法に関する一考察, 水工学論文集 第 45 巻, pp.1129-1134, 2000.

4) 辻本哲朗, 田代喬, 伊藤壮志 : 生活圈の連結性に着目 した魚類生息環境評価法の提案と河川内微地形の役 割評価，河川技術に関する論文集 第 6 巻， pp.167-172，2000.

5）知花武佳，玉井信行 : 環境傾度を考慮した魚類生息環 境評価法に関する研究,河川技術に関する論文集 第 6 巻, pp.161-166, 2000.

6）河川生態学術研究会多摩川研究グループ : 多摩川の総 合研究一永田地区を中心として一, 2000.

7）知花武佳, 玉井信行 : 魚類生息域適性曲線に関する考 察, 応用生態工学研究会 第 3 回研究発表会講演集, pp.73-76, 1999.

8) N.Tamai, T.Chibana.: Estimation of Suitability for Fishes Focused on Rapid -pool Conditions, Proceedings of FISH TREC 2001 pp.85 -94, 2001.

9) 沼田真監修, 水野信彦, 御勢久右衛門: 河川の生態学, 築地書館, pp.200-207, 1995.

10)岡滋晃, 知花武佳, 玉井信行 : 鉛直流速勾配に着目し た生態環境評価方法に関する考察, 第 5 回応用生態工 学研究会研究発表会講演集, pp.89-92, 2001.

11)野上毅, 渡邊康玄, 中津川誠, 土屋進, 岩瀬晴夫, 渡 辺恵三, 加村邦茂: 真駒内川に於ける底生魚類生息環 境の改善についての現地実験, 河川技術論文集 第 7 巻, pp. 309-314, 2000.

12)土屋十图 : 都市河川の総合親水計画，信山社サイテッ ク, pp.135-164, 1999.

13）知花武佳, 玉井信行, 黒田直樹, 鈴木一平 : 河床勾配 で区分される小区間に着目した魚類生息環境評価に 関する基礎的研究, 第 56 回年次学術講演会講演概要 集 第II部門, 2001 . 